



\section{Effectiviteit waterbad verdover bij pluimveeslachterij W. van der Meer en Zonen B.V.}

Marien Gerritzen en Henny Reimert 
Gerritzen, M., H. Reimert, 2018. Effectiviteit waterbad verdover bij pluimveeslachterij W. van der Meer en Zonen B.V. Wageningen Livestock Research, Rapport 1085.

Dit rapport is gratis te downloaden op https://doi.org/10.18174/440994 of op www.wur.nl/livestock-research (onder Wageningen Livestock Research publicaties).

(C) 2018 Wageningen Livestock Research

Postbus 338, 6700 AH Wageningen, T 03174839 53, E info.livestockresearch@wur.nl, www.wur.nl/livestock-research. Wageningen Livestock Research is onderdeel van Wageningen University \& Research.

Wageningen Livestock Research aanvaardt geen aansprakelijkheid voor eventuele schade voortvloeiend uit het gebruik van de resultaten van dit onderzoek of de toepassing van de adviezen.

Alle rechten voorbehouden. Niets uit deze uitgave mag worden vermenigvuldigd en/of openbaar gemaakt worden door middel van druk, fotokopie, microfilm of op welke wijze dan ook zonder voorafgaande toestemming van de uitgever of auteur.

De certificering volgens ISO 9001 door DNV onderstreept ons kwaliteitsniveau. Op als onze onderzoeksopdrachten zijn de Algemene Voorwaarden van de Animal Sciences Group van toepassing. Deze zijn gedeponeerd bij de Arrondissementsrechtbank Zwolle. 


\section{Inhoud}

Procesbeschrijving 


\section{$1 \quad$ Aanleiding}

Naar aanleiding van de discussie tussen slachterij W. van de Meer en Zonen B.V. en de toezichthouder over de noodzaak voor het permanent plaatsen van een na-controleur bij het automatisch aansnijden van leghennen is er door de slachterij aan Wageningen UR advies gevraagd over de noodzaak hiervan. Door de slachterij wordt gesteld dat de instelling van de elektrische verdoving dusdanig is dat er geen sprake is van een eenvoudige verdoving maar dat de dieren onomkeerbaar worden verdoofd waarmee de noodzaak van een permanente nacontrole overbodig is.

Doel van de observaties door Wageningen UR is vaststellen of er sprake is van een onomkeerbaar verdovingsproces. 


\section{$2 \quad$ Procesbeschrijving}

Leghennen worden aangevoerd in kratten, 15 dieren per krat. Vanuit de kratten worden de hennen door 4 personen aangehangen aan de slachtlijn. De dieren worden vrij los in de slachthaken gehangen waarna de dieren tussen geleide platen (foto 2) met een lijnsnelheid van 75 dieren per minuut worden getransporteerd naar de automatisch poten aandruk machine (foto 3). Via een borstgeleidingsplaat worden de dieren het waterbad ingebracht. De tijd tussen laatste aanhanger en start verdoven is 54 seconden. De dieren verblijven met 9 dieren gelijktijdig gedurende 6 seconden in de verdover. De tijd tussen einde verdoven en aansnijden is 30 seconden. 


\section{$3 \quad$ Uitvoering}

Gedurende 3 slachtdagen is bij 350 leghennen van 6 verschillende koppels vastgesteld of de dieren correct waren verdoofd en of de verdoving onomkeerbaar was.

Random werden 5 dieren per keer van de slachtlijn gehaald en op een tafel gelegd (foto 6). Zodra de dieren op de tafel lagen, 10 seconden na einde verdoven, en vervolgens met een interval van 30 seconden gedurende 5 minuten zijn de oogreflexen, dreigreflex, reactie op een pijnprikkel, ademhaling en oprichtreflex beoordeeld. De observaties zijn uitgevoerd door een 2 getrainde medewerkers van Wageningen UR. 


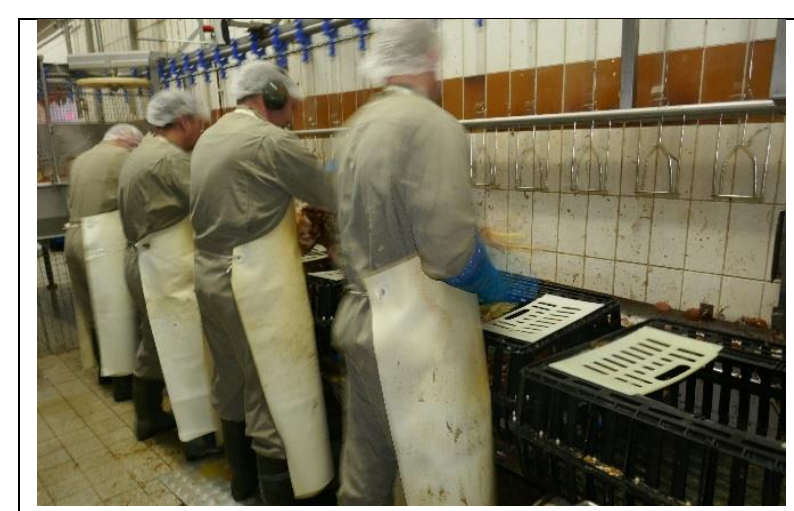

Foto 1: aanhangen

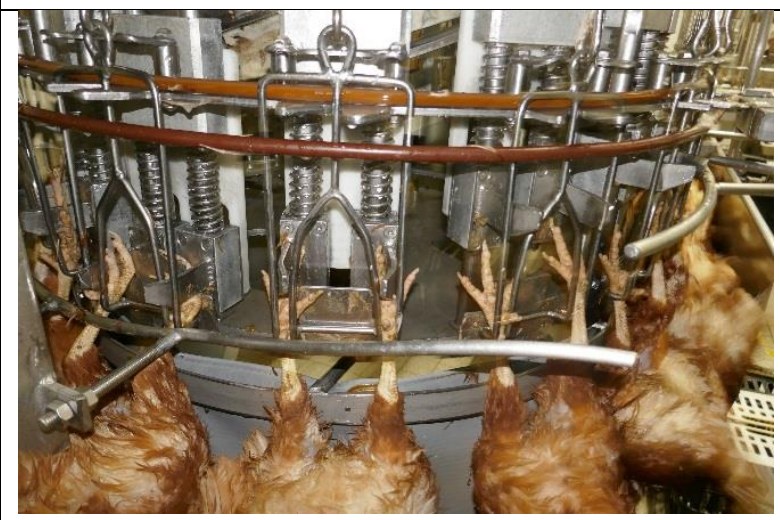

Foto 3: looppoten aandrukken

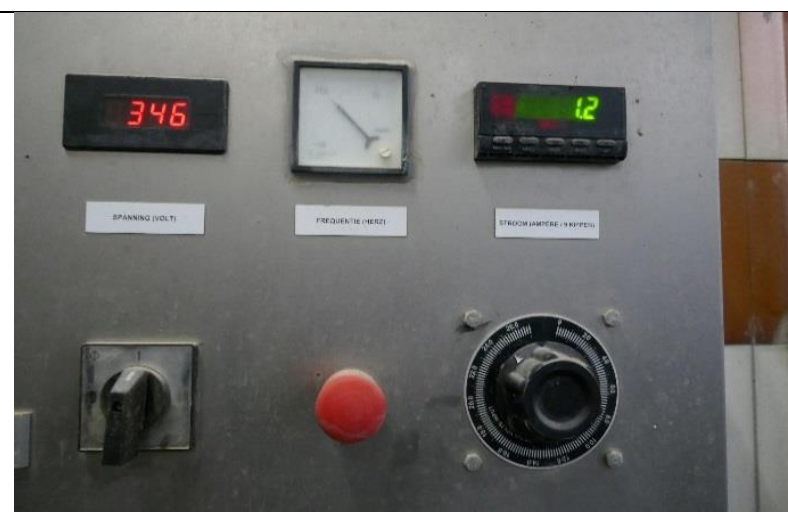

Foto 5: Instellingen waterbad

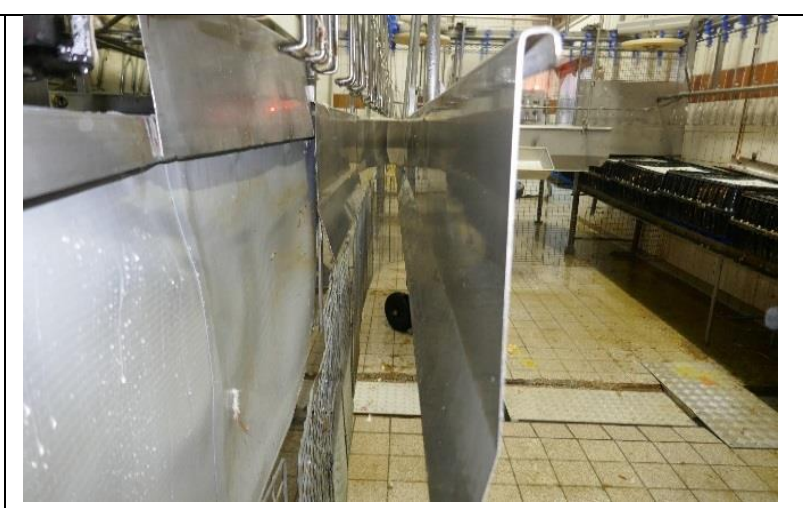

Foto 2: geleiding voor kippen

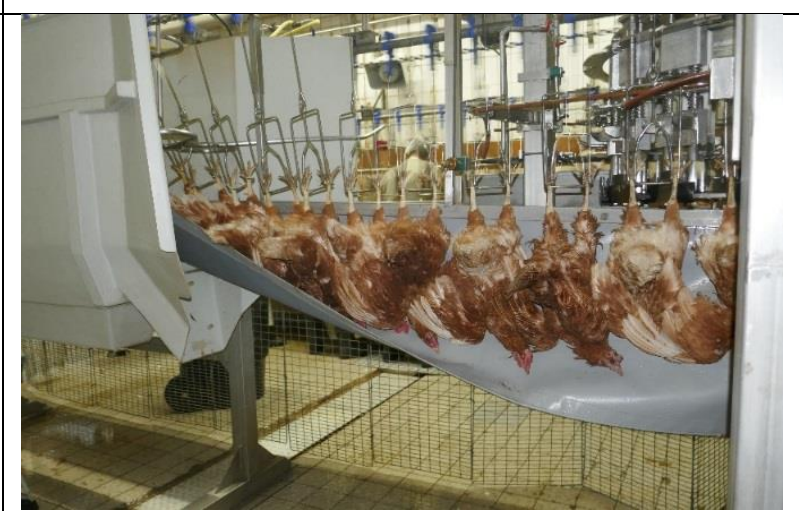

Foto 4: geleiding inloop waterbad

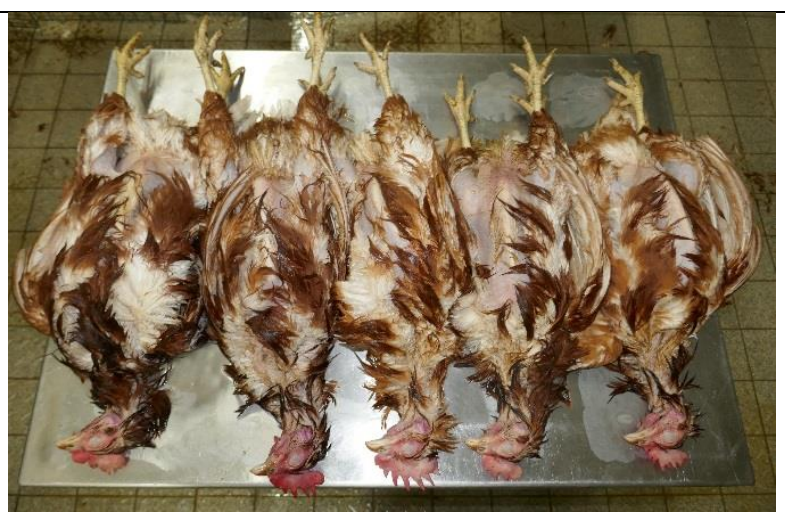

Foto 6: Beoordeling verdoving 


\section{Resultaten}

Alle dieren zijn gedurende 6 seconden blootgesteld aan $50 \mathrm{~Hz}$ en ca 340 Volt (foto 5) dit resulteerde in een effectieve stroomsterkte van 1,0 tot 1,4 ampère wat neerkomt op gemiddeld $111-155 \mathrm{~mA}$ per dier.

In totaal zijn er 350 dieren beoordeeld in groepjes van 5 dieren tegelijk. Op dag 1 is zijn 60 dieren van 1 koppel (bruine hennen) beoordeeld. Direct na de pauze werd bij 2 dieren uit een groepje van 5 direct na verdoven een positieve ooglidreflex en een positieve reactie op de pijnprikkel waargenomen. Deze dieren zijn direct opnieuw verdoofd en verbloed.

Vervolgens werd bij 1 dier een ritmische ademhaling waargenomen na 2 minuut en 45 seconden richtte dit dier zich op. Ook dit dier is direct opnieuw verdoofd en verbloed. Alle overige 57 dieren op dag 1 waren irreversibel verdoofd.

Op dag 2 zijn van 3 verschillende koppels ( 2 koppels bruine biologische en 1 koppel bruine scharrel hennen) in totaal 140 dieren beoordeeld volgens de zelfde werkwijze. Geen van deze dieren reageerde op toegediende prikkels en waren allemaal irreversibel verdoofd. Op dag 3 zijn van 2 verschillende koppels, 1 koppel witte biologische hennen en 1 koppel bruine scharrel hennen, 150 dieren beoordeeld volgens de beschreven werkwijze. Geen van de 150 dieren reageerde op de toegediende prikkels. Bij geen enkel dier is na verdoven een ademhaling waargenomen. Alle dieren op dag 3 waren irreversibel verdoofd. 


\section{$5 \quad$ Conclusies}

Het slachtproces verloopt rustig en de dieren worden met aandacht voor het dierenwelzijn behandeld. De toegepaste verdoving voldoet ruimschoots aan VO 1099/2009.

$\mathrm{Bij}$ 99.4\% van de leghennen resulteerde de toegepaste verdoving in een adequate bewusteloosheid en bij 99,1\% van de dieren in een irreversibele bewusteloosheid met de dood tot gevolg.

Het is niet duidelijk waarom 2 dieren op dag 1 niet goed waren verdoofd maar dit lijkt een incident te zijn.

Het dier met een oprichtreflex op 2 minuten en 45 seconden was voldoende lang bewusteloos om te garanderen dat dit dier gedurende verbloeden niet meer bij bewustzijn zou zijn gekomen. 


\section{Advies}

Het verdovings- en dodingstraject verloopt erg goed, aanpassingen aan dit traject worden dan ook niet geadviseerd.

Permanente nacontrole bij het automatisch aansnijden wordt op basis van de bevindingen niet noodzakelijk geacht. 



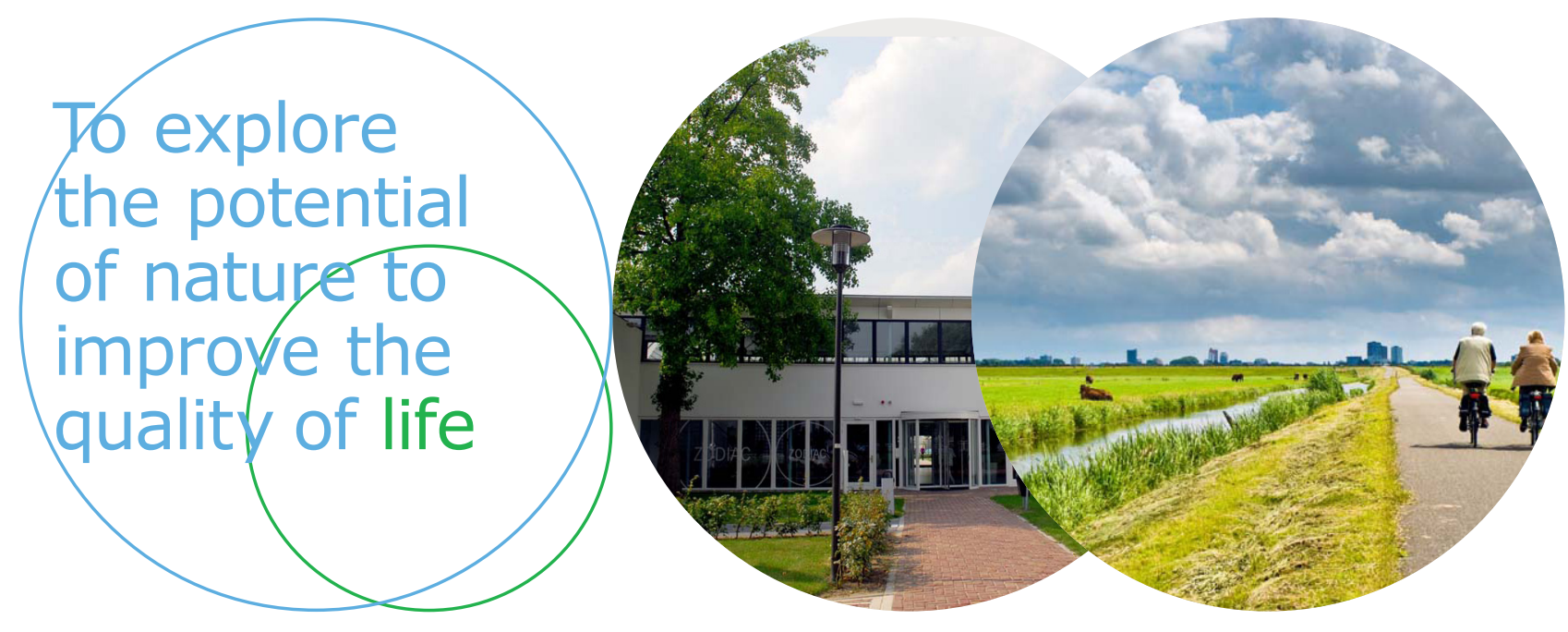

Wageningen Livestock Research Postbus 338

Wageningen Livestock Research ontwikkelt kennis voor een zorgvuldige en 6700 AH Wageningen

T 0317483953 renderende veehouderij, vertaalt deze naar praktijkgerichte oplossingen en innovaties, en zorgt voor doorstroming van deze kennis. Onze wetenschappelijke E info.livestockresearch@wur.nl www.wur.nl/ livestock-research kennis op het gebied van veehouderijsystemen en van voeding, genetica, welzijn en milieu-impact van landbouwhuisdieren integreren we, samen met onze klanten, tot veehouderijconcepten voor de $21 \mathrm{e}$ eeuw.

De missie van Wageningen University \& Research is 'To explore the potential of nature to improve the quality of life'. Binnen Wageningen University \& Research bundelen 9 gespecialiseerde onderzoeksinstituten van Stichting Wageningen Research en Wageningen University hun krachten om bij te dragen aan de oplossing van belangrijke vragen in het domein van gezonde voeding en leefomgeving. Met ongeveer 30 vestigingen, 6.500 medewerkers en 10.000 studenten behoort Wageningen University \& Research wereldwijd tot de aansprekende kennisinstellingen binnen haar domein. De integrale benadering van de vraagstukken en de samenwerking tussen verschillende disciplines vormen het hart van de unieke Wageningen aanpak. 